\title{
Isolation and Identification of Endophytic Bacteria from Mycorrhizal Tissues of Terrestrial Orchids from Southern Chile
}

\author{
Héctor Herrera ${ }^{1} @$, Tedy Sanhueza ${ }^{1}$, Alžběta Novotná ${ }^{2}$, Trevor C. Charles ${ }^{3}(\mathbb{D}$ and \\ Cesar Arriagada 1,*(D) \\ 1 Laboratorio de Biorremediación, Facultad de Ciencias Agropecuarias y Forestales, \\ Departamento de Ciencias Forestales, Universidad de La Frontera, 4811230 Temuco, Chile; \\ hector.herrera@ufrontera.cl (H.H.); t.sanhueza01@ufromail.cl (T.S.) \\ 2 Department of Ecosystem Biology, Faculty of Science, University of South Bohemia, Branišovská 31, \\ 37005 České Budějovice, Czech Republic; alzbinovotna@gmail.com \\ 3 Department of Biology, University of Waterloo, University Avenue West, Waterloo, ON N2L 3G1, Canada; \\ trevor.charles@uwaterloo.ca \\ * Correspondence: cesar.arriagada@ufrontera.cl; Tel.: +56-045-232-5635; Fax: +56-045-234-1467
}

Received: 24 December 2019; Accepted: 24 January 2020; Published: 30 January 2020

\begin{abstract}
Endophytic bacteria are relevant symbionts that contribute to plant growth and development. However, the diversity of bacteria associated with the roots of terrestrial orchids colonizing Andean ecosystems is limited. This study identifies and examines the capabilities of endophytic bacteria associated with peloton-containing roots of six terrestrial orchid species from southern Chile. To achieve our goals, we placed superficially disinfected root fragments harboring pelotons on oatmeal agar (OMA) with no antibiotic addition and cultured them until the bacteria appeared. Subsequently, they were purified and identified using molecular tools and examined for plant growth metabolites production and antifungal activity. In total, 168 bacterial strains were isolated and assigned to 8 OTUs. The orders Pseudomonadales, Burkholderiales, and Xanthomonadales of phylum Proteobacteria were the most frequent. The orders Bacillales and Flavobacteriales of the phylla Firmicutes and Bacteroidetes were also obtained. Phosphate solubilization was detected in majority of isolates; however, it was significantly higher in Collimonas pratensis and Chryseobacterium sp. (PSI $=1.505 \pm 0.09$ and $1.405 \pm 0.24$, respectively). Siderophore production was recorded only for C. pratensis $\left(0.657 \pm 0.14 \mathrm{~mm} \mathrm{day}^{-1}\right)$, Dyella marensis $\left(0.131 \pm 0.02 \mathrm{~mm} \mathrm{day}^{-1}\right)$, and Luteibacter rhizovicinus $\left(0.343 \pm 0.12 \mathrm{~mm}^{-1 a y^{-1}}\right)$. Indole acetic acid production was highly influenced by the isolate identity; however, the significantly higher activity was recorded for Pseudomonas spp. (ranging from $5.507 \pm 1.57 \mu \mathrm{g} \mathrm{mL} \mathrm{g}^{-1}$ to $7.437 \pm 0.99 \mu \mathrm{g} \mathrm{mL}{ }^{-1}$ ). Additionally, six bacterial isolates were able to inhibit the growth of some potential plant pathogenic fungi. Our findings demonstrate the potential for plant growth promoting capabilities and some antifungal activities of endophytic bacteria inhabiting the mycorrhizal tissue of terrestrial orchids, which may contribute especially at early developmental stages of orchid seedlings.
\end{abstract}

Keywords: bacteria; endophytes; symbiosis; orchids; plant growth-promoting bacteria

\section{Introduction}

Plant endophytes cover a broad spectrum of microorganisms with beneficial, neutral, or detrimental effects on plant growth and development [1]. Worldwide, the study of endophytic microorganisms are focused mainly on fungi [2,3], but in the last decade research on bacterial endophytes has gained attention due to their high presence in various interior tissues of almost all higher plants [4-6]. 
Plant growth-promoting bacteria (PGPB) were first mentioned and examined by Kloepper and Schroth [7]. PGPB are primarily soil microorganisms living in close vicinity of plant roots (rhizosphere) under the direct influence of the root exudates [8]. From the rhizosphere, the bacteria colonize the root cortical cells and establish a symbiotic relationship with the plant host [9]. Although the bacteria are one of the most common soil microorganisms [6], only a very limited number of them can be cultivated under laboratory conditions in order to examine their beneficial capabilities $[10,11]$.

Orchidaceae is one of the most numerous plant families with more than 30,000 species and almost worldwide distribution growing under diverse climatic conditions, colonizing the soil, the bark of trees, and rocks [12]. In Chile, almost 70 orchid species occur, and their distribution, mycorrhizal associations together with the seed germination have been described by Novoa et al. [13] and Herrera et al. [14]. However, information regarding bacteria associated with native orchids is limited.

Various mycorrhizal fungi and endophytic bacteria can be isolated from orchid root tissue [15-17]. The beneficial effect of orchid mycorrhizae on seed germination and further seedling development has been described and demonstrated [18]. Orchid seeds lack the essential nutrients to sustain plant growth, needing compatible mycorrhizal fungi as the primary source of carbon for the embryo [19]. This is the main characteristic of the orchid mycorrhizal process, and several articles analyzing mycorrhizal fungi associated with orchids and their potential to promote plant growth support this [20-22]. However, the effect of endophytic bacteria on orchid development still unclear [23]. Generally, PGPB are able to promote plant growth by direct or indirect mechanisms, including phosphate solubilization activity, phytohormones production, signaling modification, protection against pathogens, and facilitation of nutrient uptake [9]. Few studies have analyzed the potential of isolated endophytic bacteria to promote plant growth [24-26]. Therefore, the mechanisms responsible for plant growth promotion in terrestrial orchids from Andean ecosystems need to be investigated to consider bacteria as potentially beneficial in order to ascertain a putative role of these microorganisms in symbiotic seed germination or plantlet development.

In this study we examined taxonomical diversity of culturable endophytic bacteria associated with peloton-containing root tissue of some native terrestrial orchids from southern Chile. Furthermore, we analyzed their potential beneficial traits such as phosphate solubilization, indole acetic acid (IAA) production and siderophore production together with their ability to inhibit growth of some fungal pathogens. These characteristics may play a key role in growth and development of orchid seedlings. For this, several orchids were sampled at different locations in the Region of La Araucanía (Southern Chile), inspected for the presence of mycorrhizal structures, and bacteria associated with the mycorrhizal root segments were isolated, cultured, and identified to explore their plant growth promotion capabilities.

\section{Materials and Methods}

\subsection{Sampling}

The roots of six terrestrial orchid species were sampled at five localities of the Andean and Coastal ecosystem in the Region of La Araucanía in southern Chile (December 2018-February 2019; Table 1). The identification of the orchid species was performed based on floral characteristics according to Novoa et al. [13]. The species of interest occurred in grasslands and understoreys of native and exotic forests, colonizing the first $15 \mathrm{~cm}$ of soil (Table 1). Mycorrhizal root segments (brownish zones within a root) were collected from the rhizomes growing within the upper part of soil and kept in paper bags for further laboratory processing. The study material was sampled from 10 plants per examined orchid species (where orchid populations were large). 
Table 1. List of plants and locations of orchids sampled in the experiments.

\begin{tabular}{cccc}
\hline Species & Location & Sample Site & $\begin{array}{c}\text { Number of } \\
\text { Root Samples }\end{array}$ \\
\hline Chloraea barbata Lindl. & Imperial $\left(38^{\circ} 43^{\prime} 31.5^{\prime \prime} \mathrm{S} 72^{\circ} 59^{\prime} 45.0^{\prime \prime} \mathrm{W}\right)$ & Grassland & 10 \\
Chloraea collicensis Kraenzl. & Cholchol $\left(38^{\circ} 36^{\prime} 40.9^{\prime \prime} \mathrm{S} 72^{\circ} 49^{\prime} 16.0^{\prime \prime} \mathrm{W}\right)$ & Grassland & 10 \\
Chloraea gavilu Lindl. & Malalche $\left(38^{\circ} 34^{\prime} 01.7^{\prime \prime} \mathrm{S} 72^{\circ} 56^{\prime} 57.3^{\prime \prime} \mathrm{W}\right)$ & Understorey exotic forest & 10 \\
Chloraea magellanica Hook. F. & Galletue $\left(38^{\circ} 37^{\prime} 05.8^{\prime \prime} \mathrm{S} 71^{\circ} 26^{\prime} 02.4^{\prime \prime} \mathrm{W}\right)$ & Grassland & 10 \\
Gavilea Araucana (Phil.) M.N. Correa & Malalche $\left(38^{\circ} 33^{\prime} 38.5^{\prime \prime} \mathrm{S} 72^{\circ} 56^{\prime} 19.5^{\prime \prime} \mathrm{W}\right)$ & Understorey native forest & 4 \\
Gavilea lutea (Pers.) M.N. Correa & Melipeuco $\left(38^{\circ} 45^{\prime} 02.8^{\prime \prime} \mathrm{S} 71^{\circ} 36^{\prime} 09.8^{\prime \prime} \mathrm{W}\right)$ & Understorey native forest & 4 \\
\hline
\end{tabular}

\subsection{Isolation of Endophytic Bacteria}

Isolation of bacteria was performed following the standard protocol for isolation of mycorrhizal fungi from peloton-containing roots [15]. Briefly, the collected roots were washed under tap water and cut into $3 \mathrm{~cm}$ segments. They were surface-sterilized (disinfection solution comprising 90:5:5 of sterile deionized water, ethanol $96 \%$ and sodium hypochlorite solution ( $5 \%$ active chlorine)) for $10 \mathrm{~min}$ under continuous agitation, followed by five rinsings in sterile deionized water under a laminar flow cabinet. Additionally, $300 \mu \mathrm{L}$ of the last wash were dispersed on potato dextrose agar (PDA; supplemented with $100 \mathrm{mg} \mathrm{L}^{-1}$ cycloheximide) and Luria-Bertani Agar (LBA; supplemented with $100 \mathrm{mg} \mathrm{L}^{-1}$ cycloheximide) to ensure no contamination with surface-adherent ectobacteria. Afterwards, the roots were transversally sliced and visually inspected for the presence of hyphal coils inside the root cortex (pelotons). Brownish zones containing pelotons were separated from non-colonized root segments using a sterile scalpel and the pelotons were placed on PDA and LBA media and incubated for 3 weeks at $27 \pm 1{ }^{\circ} \mathrm{C}$, or until bacterial growth appeared near the root segment. Subsequently, they were subcultured on LBA, incubated at $27 \pm 1^{\circ} \mathrm{C}$, and stored at $4{ }^{\circ} \mathrm{C}$ for further analyses.

\subsection{Molecular Identification of Bacteria}

Molecular identification of bacteria was performed based on the sequence of the $16 \mathrm{~S}$ ribosomal RNA gene. DNA was extracted from liquid cultures of bacteria in Luria-Bertani broth (LBB) using the UltraClean ${ }^{\circledR}$ Microbial DNA Isolation Kit (Mo Bio Laboratories. Carlsbad, CA), according to the manufacturer's instructions. PCR amplifications were performed using the universal primer pair for bacteria 27F (5'-AGAGTTTGATCCTGGCTCAG-3') and 1492R (5'-TACGGTTACCTTGTTACGACTT-3') according to Zhang et al. [27]. The PCR cycle consisted of an initial denaturing at $95^{\circ} \mathrm{C}$ for $5 \mathrm{~min}$, followed by 30 cycles of denaturing at $95^{\circ} \mathrm{C}$ for $1 \mathrm{~min}$ each, annealing at $58^{\circ} \mathrm{C}$ for $1 \mathrm{~min}$, an extension at $72{ }^{\circ} \mathrm{C}$ for $1 \mathrm{~min}$ and a final extension for $5 \mathrm{~min}$ at $72{ }^{\circ} \mathrm{C}$. PCR products were checked in $2 \%$ agarose gel stained with GelRed ${ }^{\circledR}$. Sequencing was performed by Macrogen (Seoul, South Korea).

BLAST searches were conducted to find the closest match, accepting the genus and species classification according to Chen et al. [28]. The sequences were aligned and edited using the ClustalX and BioEdit software $[29,30]$. The phylogenetic relationships were estimated using the neighbor-joining method in the MEGA X software [31], according to Herrera et al. [32]. The obtained sequences were submitted to the GenBank database under the codes MK790613-MK790627.

\subsection{Screening of Plant Growth-Promoting Traits}

Potential plant growth-promoting characteristics were evaluated as in Ortiz et al. [33] with modifications. Briefly, phosphate solubilization was estimated on Pikovskaya agar plates containing tricalcium phosphate $\left(\mathrm{Ca}_{3}\left(\mathrm{PO}_{4}\right)_{2}\right)$ as the insoluble phosphate source and incubated in the dark at $27 \pm 1{ }^{\circ} \mathrm{C}$ for 14 days. The phosphate solubilization capability was positive if a clear halo around the bacteria was present. A phosphate solubilization index (PSI) was estimated by the diameter of the halo $(\mathrm{mm}) /$ diameter of colony $(\mathrm{mm})$, with 10 repetitions per bacterium. Siderophore production was estimated using the chrome azurol S (CAS) agar [34]. Plates were incubated in the dark at $27 \pm 1^{\circ} \mathrm{C}$ for 7 days. CAS-reaction rates were expressed in mm per day, considering 10 replicates per bacterial strain. To examine IAA production, bacteria were cultured in LBB supplemented with $0.5 \mathrm{mg} \mathrm{mL}^{-1}$ 
of L-tryptophan and incubated at $27 \pm 1{ }^{\circ} \mathrm{C}$ for 14 days under agitation at $150 \mathrm{rpm}$. Then $2 \mathrm{~mL}$ of cell suspension were mixed with $4 \mathrm{~mL}$ of Salkowski's reagent and incubated at room temperature in darkness for $30 \mathrm{~min}$. The absorbance was measured at $530 \mathrm{~nm}$ considering 10 replicates per bacterium.

\subsection{Antifungal Activity}

Antifungal activity of the obtained bacteria was tested on several isolates of potential fungal pathogens (Phoma sp., Ulocladium consortiale, Fusarium sp., Botrytis cinerea, Alternaria infectoria, and one orchid mycorrhizal fungus previously isolated from Chloraea philippi, Ceratobasidium sp. (accession number MK793002)) kept in the fungal bank of the Bioremediation Laboratory at the Universidad de La Frontera. The tested procedure was developed following Petatan-Sagahon et al. [35] with modifications. Briefly, a particular bacterial strain was inoculated at $2 \mathrm{~cm}$ distance from a plug (ø $5 \mathrm{~mm}$ ) with fungal hyphae placed in the center of petri plate with PDA; five replicates were prepared per examined fungal strain. The plates were incubated in darkness at $27 \pm 1{ }^{\circ} \mathrm{C}$ for 7 days and visually inspected every $24 \mathrm{~h}$. The inhibition rate was considered positive when distinctive deceleration of mycelial growth was observed compared to a control treatment without bacterial inoculation.

\subsection{Data Analyses}

Quantitative analyses were performed using a one-way analysis of variance (ANOVA), considering each bacterium as treatment. To evaluate significant differences between treatments, post hoc pair-wise comparisons were performed, using the SD of means and Tukey's test, establishing statistical significance at $p<0.05$. All statistical tests were conducted using the R software (R Core Team 2018; https: //www.R-project.org).

\section{Results}

In total 15 endobacterial strains were obtained from the mycorrhizal tissues of the examined orchid species with a variable diversity (Table 2; Table S1). The frequency of isolation of bacteria from the mycorrhizal fragments varied from 15 to $38 \%$ in Gavilea lutea and Chloraea barbata, respectively.

In total, 168 bacterial colonies were obtained from the pelotons containing tissues. The greatest diversity of bacteria was found in G. lutea and Chloraea magellanica, which showed the presence of 8 and 7 different bacterial strains (Figure 1). The isolation of bacteria varied according to the orchids: (i) six bacterial strains were isolated from C. barbata (strains CM01, CB01, CC03, GA01, GA03, and CM03), accounting 14 bacterial colonies (Figure 1); (ii) five bacterial strains were isolated from Chloraea collicensis (strains CG01, CC01, CC02, CC03, and CC04), accounting 32 bacterial colonies (Figure 1); (iii) five bacterial strains were detected in Chloraea gavilu (strains CG01, CC02, CC03, CC04 and GA02), accounting 21 bacterial colonies (Figure 1); (iv) seven bacterial strains were isolated from C. magellanica (strains CM01, GL01, CC04, GL02, CM02, CM03 and CM04), accounting 40 bacterial colonies (Figure 1); (v) five bacterial strains were isolated from Gavilea araucana (strains CG01, CC02, GA01, GL02, and GA04), accounting 31 bacterial colonies (Figure 1); and (vi) eight bacterial strains were isolated from G. lutea (strains CM01, GL01, CC02, CC04, GL02, GA02, CM02, and CM04), accounting 30 bacterial colonies (Figure 1). They were subsequently clustered into 8 OTUs (Table 2; Figure 2). The isolates GL01 and CM01 were the most frequent with the frequency of isolation, 0.10 and 0.09 , respectively Table S1. They were obtained from the roots of $C$. magellanica and G. araucana, accounting for 17 and 15 colonies, respectively (Figure 1). 
Table 2. Molecular identification of culturable bacteria isolated from peloton-containing root segments based on the closest match in the GenBank database.

\begin{tabular}{|c|c|c|c|c|c|c|}
\hline $\begin{array}{l}\text { Isolated } \\
\text { Bacteria }\end{array}$ & $\begin{array}{c}\text { GenBank } \\
\text { Accession Number }\end{array}$ & Isolation Source & Close Relatives (Accession Number) & $\%$ Identity & Source & Reference \\
\hline CM01 & MK790613 & Chloraea magellanica & Collimonas pratensis (KU311457) & 100 & Not defined & GenBank \\
\hline GL01 & MK790614 & Gavilea lutea & $\begin{array}{l}\text { Pseudomonas sp. } \\
\text { (MK371074) }\end{array}$ & 100 & Permafrost soil & GenBank \\
\hline CG01 & MK790615 & Chloraea gavilu & Pandoraea oxalativorans (CР011253) & 100 & Soil litter close to Oxalic sp. & Sahin et al. [36] \\
\hline CB01 & MK790616 & Chloraea barbata & Pseudomonas koreensis (KT008003) & 100 & $\begin{array}{l}\text { Rhizosphere from } \\
\text { metallophyte plants }\end{array}$ & Benidire et al. [37] \\
\hline $\mathrm{CC} 01$ & MK790617 & C. collicensis & Exiguobacterium aurantiacum (MH819695) & 100 & Coastal soil & Genbank \\
\hline $\mathrm{CC} 02$ & MK790618 & C. collicensis & $\begin{array}{l}\text { Dyella marensis } \\
\text { (KF475806) }\end{array}$ & 100 & Tea roots & GenBank \\
\hline $\mathrm{CC03}$ & MK790619 & C. collicensis & $\begin{array}{l}\text { Luteibacter rhizovicinus } \\
\text { (AY785744) }\end{array}$ & 100 & Tree roots & Leigh et al. [38] \\
\hline $\mathrm{CC} 04$ & MK790620 & C. collicensis & Bacillus sp.(KX959542) & 99 & Orchid mycorrhizal fungi & Novotna and Suárez [24] \\
\hline GL02 & MK790621 & G. lutea & $\begin{array}{l}\text { Pseudomonas sp. } \\
\text { (KY849590) }\end{array}$ & 100 & Roots & GenBank \\
\hline GA01 & MK790622 & G. araucana & Pseudomonas azotoformans (MF598585) & 100 & $\begin{array}{l}\text { Sporomes of Lactarius } \\
\text { salmonicolor }\end{array}$ & GenBank \\
\hline GA02 & MK790623 & G. araucana & $\begin{array}{l}\text { Pseudomonas sp. } \\
\text { (MG833398) }\end{array}$ & 99 & Tailing soils & GenBank \\
\hline GA03 & MK790624 & G. araucana & $\begin{array}{l}\text { Pseudomonas azotoformans } \\
\text { (MF598585) }\end{array}$ & 100 & $\begin{array}{l}\text { Sporomes of Lactarius } \\
\text { salmonicolor }\end{array}$ & GenBank \\
\hline CM02 & MK790625 & C. magellanica & $\begin{array}{l}\text { Chryseobacterium sp. } \\
\text { (KC306432) }\end{array}$ & 99 & Frog skin & GenBank \\
\hline CM03 & MK790626 & C. magellanica & $\begin{array}{l}\text { Pseudomonas sp. } \\
\text { (MH392636) }\end{array}$ & 99 & Water & GenBank \\
\hline CM04 & MK790627 & C. magellanica & $\begin{array}{l}\text { Pseudomonas costantinii } \\
\text { (KP218045) }\end{array}$ & 100 & Pleurotus ostreatus meia & GenBank \\
\hline
\end{tabular}




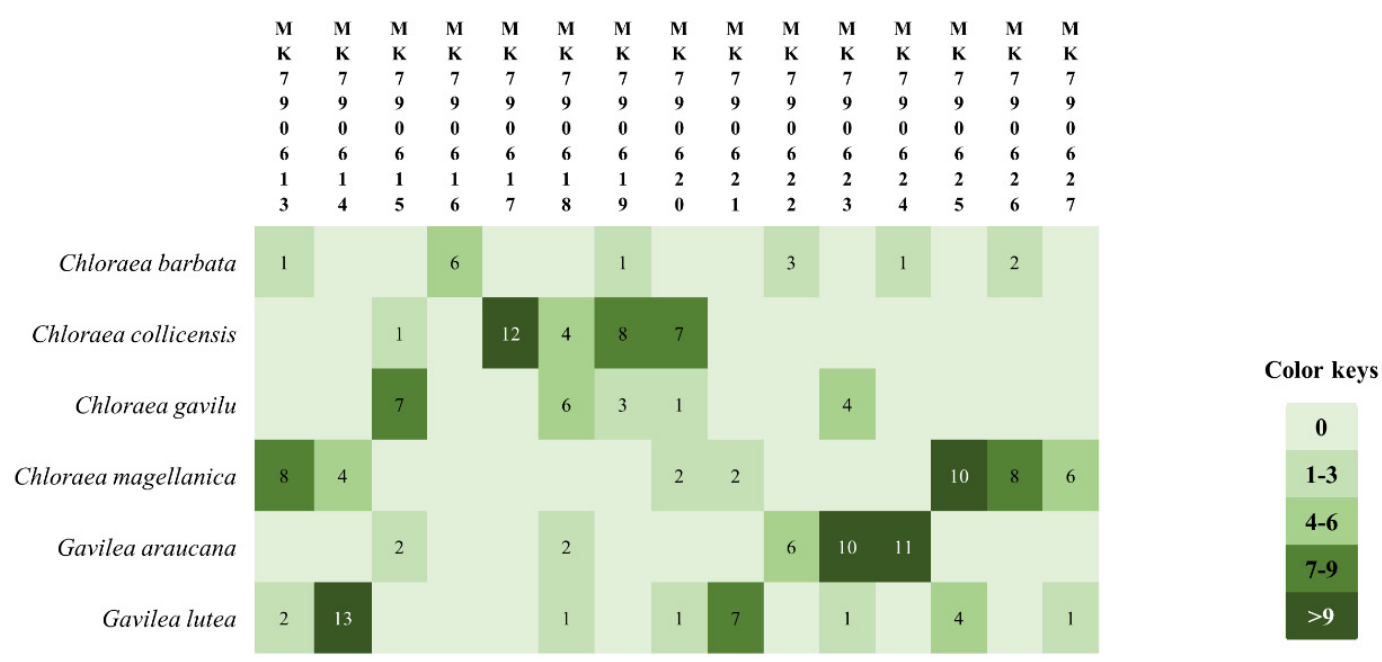

Figure 1. Heat map of abundance of bacterial strains isolated from peloton-containing roots.

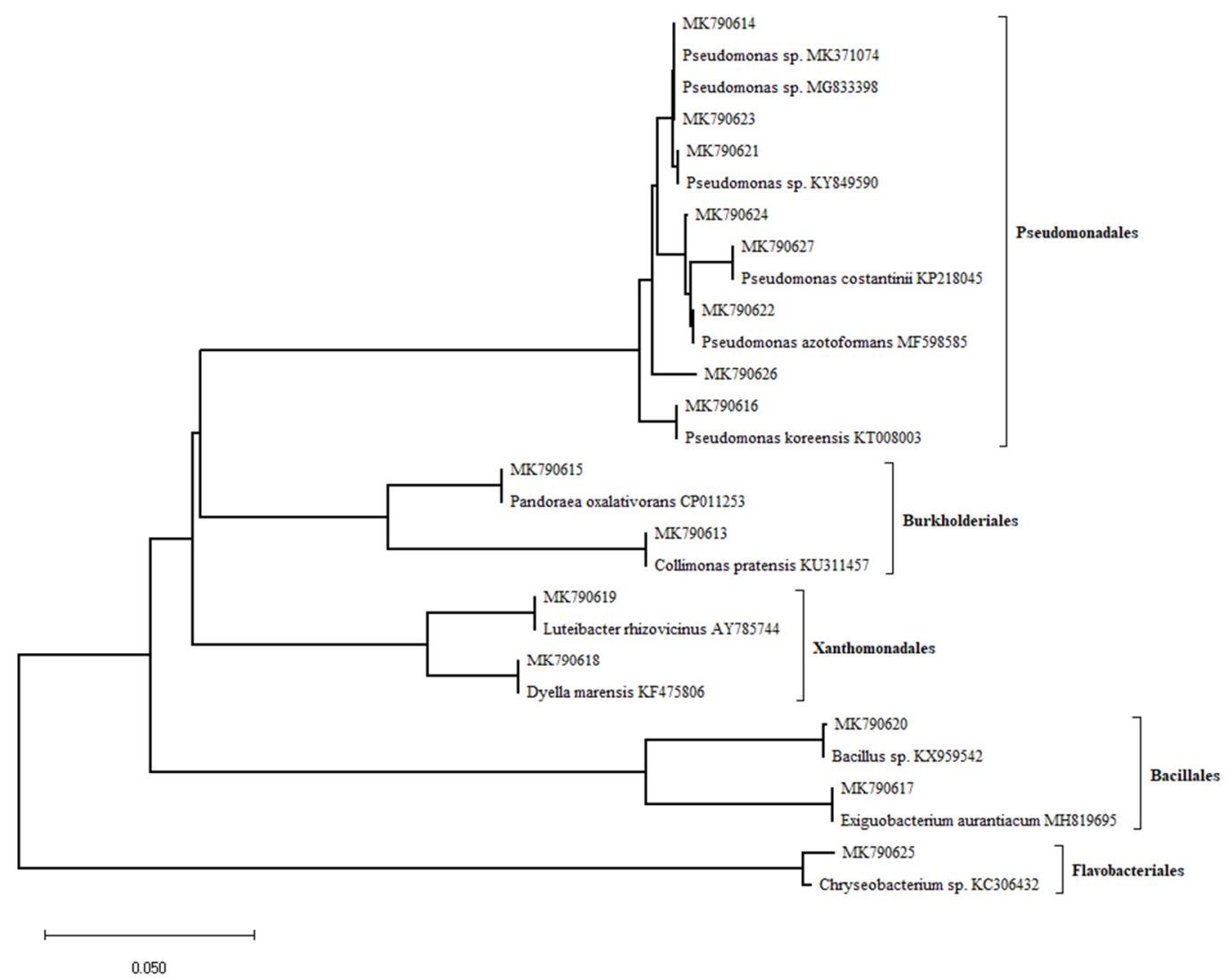

Figure 2. Maximum-likelihood tree of $16 \mathrm{~S}$ rRNA gene sequences of bacterial isolates, showing relationships in terms of distance. Numbers near branches refer to bootstrap support values. Names in capital letters between branches refer to bacterial phyla.

Most of the obtained isolates belonged to the phylum Proteobacteria. The isolates GA02, GL01, GL02, GA03, CM04, GA01, CM03, and CB01 showed high similarity with strains from the order Pseudomonadales (Figure 2). Specifically, the isolates CM03, GA02, GL02, and GL01 showed high similarity (>99\%) with different Pseudomonas spp. (Table 2; Figure 2). The isolates GA01 and GA03 showed 100\% similarity with Pseudomonas azotoformans, whereas CM04 and CB01 showed 100\% similarity with Pseudomonas constantinii and Pseudomonas koreensis, respectively (Table 2; Figure 2). Additionally, the isolates CG01 and CM01 showed 100\% similarity with Collimonas pratensis and 
Pandoraea oxalativorans, respectively, included in the order Burkholderiales (Table 2; Figure 2). Furthermore, the isolates CC02 and CC03, showed 100\% similarity with Dyella marensis and Luteibacter rhizovicinus, respectively, both included in the order Xanthomonadales (Table 2; Figure 2). The phylum Firmicutes was also detected in our analyses. The isolates CC01 and CC04 match with bacterial strains from the order Bacillales (Table 2; Figure 1). The isolate CC01 showed 100\% similarity with Exiguobacterium aurantiacum, whereas CC04 showed 99\% similarity with Bacillus sp. (Table 2; Figure 2). Finally, the isolate CM02 showed 99\% similarity with Chryseobacterium sp., included in the order Flavobacteriales from the phylum Bacteroidetes (Table 2; Figure 2).

Production of plant growth metabolites was different between bacteria. Most bacterial isolates were able to solubilize phosphate, with PSI being significantly higher in C. pratensis $(1.505 \pm 0.09)$. On the other hand, isolates CG01 and CC02 did not demonstrate any P solubilization ability (Table S1). Only 3 out of 15 examined isolates showed siderophore production (CM01, CC02, CC03), whereas it was significantly higher in the isolate $C$. pratensis $(0.657 \pm 0.14)$. Production of IAA from L-tryptophan was achieved in most of the isolates. The quantification of IAA ranged from $0.799 \pm 0.13 \mu \mathrm{g} \mathrm{mL}^{-1}$ in E. aurantiacum to $6.716 \pm 0.83 \mu \mathrm{g} \mathrm{mL}^{-1}$ in Pseudomonas sp. The strains P. oxalativorans, D. marensis and Chryseobacterium sp. did not show auxin production (Table S1).

Regarding fungal growth inhibition, seven out of 15 examined isolates (CM01, CB01, CC01, CC02, GA01, GA03, and CM02) induced a reduction of the area colonized by the fungal hyphae in the Petri dish, which was highest in C. pratensis and D. marensis, showing a reduction in the hyphal growth ranging from $25 \%$ to $20 \%$ of the fungal mycelia (Table S2). This reduction was achieved in the fungi Phoma sp., U. consortiale, Fusarium sp. and A. infectoria at different intensities, whereas no significant reduction was detected in B. cinerea or Ceratobasidium sp. (Table S2).

\section{Discussion}

Our study identified bacteria associated with peloton-containing roots from several terrestrial orchids on the Pacific side of the Andes mountains in southern Chile and suggest the existence of a broad diversity of bacteria associated with mycorrhizal tissues, which has been scarcely explored in Andean ecosystems. Such bacterial isolates match with four phyla already known as common plant endophytes inhabiting seeds, roots and leaves [39,40]. Despite several studies have reported association with bacteria in orchids from different locations, particularly in epiphytic orchids [26], the study of association with partially mycoheterotrophic terrestrial orchids is limited [23,41]. Hence, we focused our study on endophytic bacteria associated with peloton-containing roots that can be isolated in the traditional isolation methods of orchid mycorrhizal fungi [15]. A common practice in the isolation of compatible mycorrhizal fungi is the addition of antibiotics such as streptomycin to avoid bacterial growth $[42,43]$. Such a practice interferes with the growth of the bacteria inhabiting orchid roots and causes an underestimation of the presence of bacteria inside pelotons that can also have positive effects on plant growth promotion, especially after the mycoheterotrophic stage, where other nutritional compounds are needed to initiate plantlet growth $[16,25]$. Certainly, carbon is the main nutritional compound required by the embryo during the protocorm stage, but when the plantlet stage starts, the nutritional demand requires other nutrients to start growth and development [44-46]. Here, plant growth-promoting bacteria can have a direct role by the production of auxin, phosphate solubilization or providing nutrients necessary to support growth and autotrophy [47].

Inside orchid roots, bacteria may interact with fungi and orchid root cells to maintain the beneficial effect of the symbiosis, directly by production of plant growth-promoting metabolites or indirectly by the inhibition of fungal growth that can be harmful to the plant [48-50]. Such processes have been widely reported in endophytic and rhizospheric bacteria isolated from several plants; however, association of partially mycoheterotrophic terrestrial orchids from the southern Andes has not yet been reported. Our study isolated a broad diversity of bacteria that match with genera with clear capabilities to promote plant growth, such as Pseudomonas spp., which have been reported as microorganisms able to promote Zea mays growth under normal and stressed conditions [51], to produce siderophores to 
complement iron nutrition of Vigma radiata plants [52], to improve inorganic phosphate solubilization to Pisum sativum plants [53], to improve growth of Triticum aestivum plants by auxin-producing strains [54], among others. Similarly, the genera Collimonas, Bacillus, Exiguobacterium, and Luteibacter, which were isolated in our study, have been reported as plant growth-promoting rhizobacteria that contributes to plant with beneficial metabolites such as volatile organic compounds, improve the proline and bacoside content and limit the levels of lipid peroxidation in stressed plants, or produce molecules able to chelate ferric ions and solubilize monocalcium phosphate, among others [55-57].

Our results suggest that bacteria associated with terrestrial orchids can have a positive role in plant growth promotion, which is in line with the studies of Tsavkelova et al. [41] showing root associations of Paphiopedilum appletonianum and Pholidota articulata with the genera Pseudomonas, Bacillus, and Chryseobacterium. Additionally, Galdiano et al. [58] identified Bacillus sp. strains from roots of Cattleya walkeriana. These previous works agree with our results and may reflect a widespread occurrence of these microorganisms in orchid roots and other myco-heterotrophs [59], which can differ according to the ecosystems and the physiological state of the plants. The substantial diversity of bacteria isolated in our study might relate to the diversity of plants colonizing the orchid-related sampling points, which certainly influences the diversity of endophytic bacteria $[17,60]$.

Plant growth capabilities were detected in some bacterial strains isolated in our study, especially in C. pratensis and Pseudomonas spp., which showed plant growth-promoting attributes such as phosphate solubilization and the production of IAA, which is consistent with the results obtained by Tsavkelova et al. [61], who identified several auxin-producing bacteria associated with roots of Dendrobium moschatum, as well as a beneficial effect of some endophytic bacteria on growth and root formation in two tropical orchids [41], and in the germination of the seeds [62] via indole-3-acetic acid (IAA). Similarly to our study, Faria et al. [25] isolated endophytic bacteria (Paenibacillus spp.) from roots of the orchid Cymbidium eburneum that have a positive effect to stimulate plant growth via IAA, in spite of no phosphate solubilization being reported. Certainly, production of auxin is one of the most plant growth-promoting mechanisms reported in bacteria isolated from orchids and have clear roles in plant growth promotion, especially in epiphytic orchids. In the soil, orchids need the associations with other microorganisms to improve the growth rate of the young plantlets, those with plant growth-promoting characteristics that might contribute to the plant metabolism [14]. Despite phosphate solubilization, production of siderophores and production of auxin being lower than other amounts reported in similar works, these bacteria may represent beneficial orchid endophytes that may contribute to growth and development, especially after the plantlet stage.

Inhibition of fungal growth is a characteristic that was present in seven of the bacterial isolates. C. pratensis was the most effective bacterium restricting the growth in four of the five fungi tested. Such inhibition may relate to the mycophagous nature of the genus Collimonas, which can grow at the expense of living fungal hyphae as a source of nutrients [63]. These characteristics may underline a beneficial role for the plant, in which bacteria may contribute to the control of the intraradical growth of fungi to avoid colonization of vital plant tissues. This ability has been reported by Garbeva et al. [64], who showed that the production of volatiles by C. pratensis is enhanced by the presence of fungi in a sand microcosm, which is related to the mycophagous lifestyle of the bacteria. Additionally, our results agree with Poosakkannu et al. [65], who detected this bacteria as an endophyte of Deschampsia flexuosa, as well as in living fungal hyphae of soil fungi [66]. The ability of Luteibacter sp. to colonize fungal hyphae and form a functional association has been reported in a foliar endophytic fungus isolated from Platycladus orientalis plants [67], which agrees with our results regarding bacteria colonizing mycorrhizal tissues of $C$. collicensis. Additionally, we showed that some of the bacterial strains did not survive after successive subcultures ( 3 months), which may underscore a dependence of some bacteria on plant or fungal metabolites, or reflect a symbiotic association with fungi such as the association of the orchid Stanhopea connata with the mycorrhizal fungi Serendipita sp. [24].

Certainly, the diversity of endophytic bacteria is greater than what has been reported in our study, but the culturable bacteria associated with pelotons may reflect an interesting alternative to improve 
the growth and yield of plantlets developed from orchids cultured in vitro. Likewise, the specific mechanisms in which endophytic bacteria contribute to orchid development need to be addressed in order to know the contribution of these widespread endophytes to the life cycle of terrestrial orchids.

\section{Conclusions}

Our results report for the first time bacteria associated with peloton-containing root segments of terrestrial orchids from the southern Andes. The data reported here suggest that terrestrial orchids associated with many phyla of bacteria that vary with species and have the potential to promote plant growth. Additionally, the ability of bacteria to restrict the growth of potential pathogenic fungi may contribute to the intraradical control of mycorrhizal fungus and help protect orchid roots from harmful fungi. Further studies need to test the effect of the isolated bacteria on the fungus-orchid interaction and growth.

Supplementary Materials: The following are available online at http://www.mdpi.com/1424-2818/12/2/55/s1, Table S1: Isolation frequency and plant growth promoting traits of the bacterial strains obtained from the peloton-containing root slices, Table S2: Assessment of the inhibition potential of the isolated bacterial strains on the growth of potential plant fungal pathogens.

Author Contributions: Conceptualization, H.H. and C.A.; methodology, H.H. and T.S.; validation, H.H. and C.A.; formal analysis, H.H. and C.A.; investigation, H.H.; data curation, H.H. and T.S.; writing-original draft preparation, H.H. and A.N.; writing-review and editing, T.C.C., A.N. and C.A.; funding acquisition, H.H. and C.A. All authors have read and agreed to the published version of the manuscript.

Funding: This research was funded by Fondo Nacional de Desarrollo Científico y Tecnológico (FONDECYT), grant number 1170931 to C.A. (Cesar Arriagada) and Fondo De Fomento al Desarrollo Científico y Tecnológico (FONDEF), grant number VIU17E0185 to H.H. (Héctor Herrera).

Conflicts of Interest: The authors declare no conflict of interest. The funders had no role in the design of the study; in the collection, analyses, or interpretation of data; in the writing of the manuscript; or in the decision to publish the results.

\section{References}

1. Roossinck, M.J. The good viruses: viral mutualistic symbioses. Nat. Rev. Microbiol. 2011, 9, 99. [CrossRef]

2. Novotná, A.; Benítez, Á.; Herrera, P.; Cruz, D.; Filipczyková, E.; Suárez, J.P. High diversity of root-associated fungi isolated from three epiphytic orchids in southern Ecuador. Mycoscience 2018, 59, 24-32. [CrossRef]

3. Strobel, G.A. Fungal Endophytes in Plants; MDPI: Basel, Switzerland, 2018.

4. Glazebrook, J.; Roby, D. Plant biotic interactions: from conflict to collaboration. Plant J. 2018, 93, 589-591. [CrossRef]

5. Liu, H.; Carvalhais, L.C.; Crawford, M.; Singh, E.; Dennis, P.G.; Pieterse, C.M.; Schenk, P.M. Inner plant values: diversity, colonization and benefits from endophytic bacteria. Front. Microbiol. 2017, 8, 2552. [CrossRef]

6. Glick, B.R. Plant growth-promoting bacteria: mechanisms and applications. Scientifica 2012, 963401. [CrossRef] [PubMed]

7. Kloepper, J.; Schroth, M. Plant growth promoting rhizobacteria on radish. In Proceedings of the Fourth Conference Plant Pathogenic Bacteria, Angers, France, 27 August- 2 September 1978; Gilbert-Clarey: Tours, France, 1978; pp. 876-882.

8. Compant, S.; Clément, C.; Sessitsch, A. Plant growth-promoting bacteria in the rhizo-and endosphere of plants: their role, colonization, mechanisms involved and prospects for utilization. Soil Biol. Biochem. 2010, 42, 669-678. [CrossRef]

9. Rashid, S.; Charles, T.C.; Glick, B.R. Isolation and characterization of new plant growth-promoting bacterial endophytes. Appl. Soil Ecol. 2012, 61, 217-224. [CrossRef]

10. Etesami, H.; Maheshwari, D.K. Use of plant growth promoting rhizobacteria (PGPRs) with multiple plant growth promoting traits in stress agriculture: action mechanisms and future prospects. Ecotox. Environ. Safe. 2018, 156, 225-246. [CrossRef] [PubMed]

11. Senthilkumar, M.; Krishnamoorthy, R. Isolation and characterization of tomato leaf phyllosphere Methylobacterium and their effect on plant growth. Int. J. Curr. Microbiol. Appl. Sci. 2017, 6, 2121-2136. [CrossRef] 
12. Roberts, D.L.; Dixon, K.W. Orchids. Curr. Biol. 2008, 18, R325-R329. [CrossRef] [PubMed]

13. Novoa, P.; Espejo, J.; Cisternas, M.; Rubio, M.; Dominguez, E. Guía de campo de las orquídeas chilenas; Segunda edición ampliada; Corporación Chilena de la Madera (CORMA): Santiago, Chile, 2015.

14. Herrera, H.; García-Romera, I.; Meneses, C.; Pereira, G.; Arriagada, C. Orchid Mycorrhizal Interactions on the Pacific Side of the Andes from Chile. A Review. J. Soil Sci. Plant Nut. 2019, 19, 187-202. [CrossRef]

15. Valadares, R.B.; Pereira, M.C.; Otero, J.T.; Cardoso, E.J. Narrow fungal mycorrhizal diversity in a population of the orchid Coppensia doniana. Biotropica 2012, 44, 114-122. [CrossRef]

16. Bayman, P.; Otero, J.T. Microbial endophytes of orchid roots. In Microbial Root Endophytes; Springer: New York, NY, USA, 2006; pp. 153-177.

17. Tsavkelova, E. Bacteria associated with orchid roots. In Bacteria in Agrobiology: Plant Growth Responses; Springer: New York, NY, USA; pp. 221-258.

18. McCormick, M.K.; Taylor, D.L.; Whigham, D.F.; Burnett, R.K., Jr. Germination patterns in three terrestrial orchids relate to abundance of mycorrhizal fungi. J. Ecol. 2016, 104, 744-754. [CrossRef]

19. Dearnaley, J.; Perotto, S.; Selosse, M.A. Structure and development of orchid mycorrhizas. In Molecular Mycorrhizal Symbiosis; Martin, E., Ed.; Springer: Berlin, Germany, 2016; pp. 63-86.

20. Zettler, L.W.; Corey, L.L. Orchid Mycorrhizal Fungi: Isolation and Identification Techniques. In Orchid Propagation: From Laboratories to Greenhouses-Methods and Protocols; Springer: New York, NY, USA, 2018; pp. 27-59.

21. McCormick, M.K.; Whigham, D.F.; Canchani-Viruet, A. Mycorrhizal fungi affect orchid distribution and population dynamics. New Phytol. 2018, 219, 1207-1215. [CrossRef]

22. Huang, H.; Zi, X.-M.; Lin, H.; Gao, J.-Y. Host-specificity of symbiotic mycorrhizal fungi for enhancing seed germination, protocorm formation and seedling development of over-collected medicinal orchid, Dendrobium devonianum. J. Microbiol. 2018, 56, 42-48. [CrossRef]

23. Girija, D.; Rajeevan, P.; Balakrishnan, S.; Panchami, P.; Mohan, M. 16S rRNA gene taxonomic profiling of endophytic bacteria associated with phalaenopsis roots. J. Hortic. Sci. 2018, 13, 103-107.

24. Novotna, A.; Suárez, J. Molecular detection of bacteria associated with Serendipita sp., a mycorrhizal fungus from the orchid Stanhopea connata Klotzsch in southern Ecuador. Bot. Lett. 2018, 165, 307-313. [CrossRef]

25. Faria, D.C.; Dias, A.C.F.; Melo, I.S.; de Carvalho Costa, F.E. Endophytic bacteria isolated from orchid and their potential to promote plant growth. World J. Microbiol. Biotechnol. 2013, 29, 217-221. [CrossRef]

26. Tsavkelova, E.; Cherdyntseva, T.; Netrusov, A. Bacteria associated with the roots of epiphytic orchids. Microbiology 2004, 73, 710-715. [CrossRef]

27. Zhang, X.; Gao, Z.; Zhang, M.; Jing, F.; Du, J.; Zhang, L. Analysis of endophytic actinobacteria species diversity in the stem of Gynura cusimbua by 16 S rRNA gene clone library. Microbiology 2016, 85, 379-385. [CrossRef]

28. Chen, J.; Hu, K.-X.; Hou, X.-Q.; Guo, S.-X. Endophytic fungi assemblages from 10 Dendrobium medicinal plants (Orchidaceae). World J. Microbiol. Biotechnol. 2011, 27, 1009-1016. [CrossRef]

29. Larkin, M.A.; Blackshields, G.; Brown, N.; Chenna, R.; McGettigan, P.A.; McWilliam, H.; Valentin, F.; Wallace, I.M.; Wilm, A.; Lopez, R. Clustal W and Clustal X version 2.0. Bioinformatics 2007, 23, 2947-2948. [CrossRef] [PubMed]

30. Hall, T.A. BioEdit: a user-friendly biological sequence alignment editor and analysis program for Windows 95/98/NT. Nucl. Acids. Symp. Ser. 1999, 41, 95-98.

31. Kumar, S.; Stecher, G.; Li, M.; Knyaz, C.; Tamura, K. MEGA X: molecular evolutionary genetics analysis across computing platforms. Mol. Biol. Evol. 2018, 35, 1547-1549. [CrossRef] [PubMed]

32. Herrera, H.; Valadares, R.; Contreras, D.; Bashan, Y.; Arriagada, C. Mycorrhizal compatibility and symbiotic seed germination of orchids from the Coastal Range and Andes in south central Chile. Mycorrhiza 2017, 27, 175-188. [CrossRef] [PubMed]

33. Ortiz, J.; Soto, J.; Almonacid, L.; Fuentes, A.; Campos-Vargas, R.; Arriagada, C. Alleviation of metal stress by Pseudomonas orientalis and Chaetomium cupreum strains and their effects on Eucalyptus globulus growth promotion. Plant Soil 2019, 436, 449-461. [CrossRef]

34. Milagres, A.M.; Machuca, A.; Napoleao, D. Detection of siderophore production from several fungi and bacteria by a modification of chrome azurol S (CAS) agar plate assay. J. Microbiol. Methods 1999, 37, 1-6. [CrossRef] 
35. Petatan-Sagahon, I.; Anducho-Reyes, M.A.; Silva-Rojas, H.V.; Arana-Cuenca, A.; Tellez-Jurado, A.; Cárdenas-Álvarez, I.O.; Mercado-Flores, Y. Isolation of bacteria with antifungal activity against the phytopathogenic fungi Stenocarpella maydis and Stenocarpella macrospora. Int. J. Mol. Sci. 2011, 12, 5522-5537. [CrossRef]

36. Sahin, N.; Tani, A.; Kotan, R.; Sedláček, I.; Kimbara, K.; Tamer, A.U. Pandoraea oxalativorans sp. nov., Pandoraea faecigallinarum sp. nov. and Pandoraea vervacti sp. nov., isolated from oxalate-enriched culture. Int. J. Syst. Evol. Microbiol. 2011, 61, 2247-2253. [CrossRef]

37. Benidire, L.; Pereira, S.; Castro, P.M.; Boularbah, A. Assessment of plant growth promoting bacterial populations in the rhizosphere of metallophytes from the Kettara mine, Marrakech. Environ. Sci. Pollut. Res. 2016, 23, 21751-21765. [CrossRef]

38. Leigh, M.B.; Prouzová, P.; Macková, M.; Macek, T.; Nagle, D.P.; Fletcher, J.S. Polychlorinated biphenyl (PCB)-degrading bacteria associated with trees in a PCB-contaminated site. Appl. Environ. Microbiol. 2006, 72, 2331-2342. [CrossRef]

39. Chimwamurombe, P.M.; Grönemeyer, J.L.; Reinhold-Hurek, B. Isolation and characterization of culturable seed-associated bacterial endophytes from gnotobiotically grown Marama bean seedlings. FEMS Microbiol. Ecol. 2016, 92, fiw083. [CrossRef]

40. Reinhold-Hurek, B.; Bünger, W.; Burbano, C.S.; Sabale, M.; Hurek, T. Roots shaping their microbiome: global hotspots for microbial activity. Annu. Rev. Phytopatol. 2015, 53, 403-424. [CrossRef]

41. Tsavkelova, E.A.; Cherdyntseva, T.A.; Botina, S.G.; Netrusov, A.I. Bacteria associated with orchid roots and microbial production of auxin. Microbiol. Res. 2007, 162, 69-76. [CrossRef]

42. Tan, X.M.; Wang, C.L.; Chen, X.M.; Zhou, Y.Q.; Wang, Y.Q.; Luo, A.X.; Liu, Z.H.; Guo, S.X. In vitro seed germination and seedling growth of an endangered epiphytic orchid, Dendrobium officinale, endemic to China using mycorrhizal fungi (Tulasnella sp.). Sci. Hortic. 2014, 165, 62-68. [CrossRef]

43. Wilkinson, K.; Dixon, K.; Sivasithamparam, K. Interaction of soil bacteria, mycorrhizal fungi and orchid seed in relation to germination of Australian orchids. New Phytol. 1989, 112, 429-435. [CrossRef]

44. Cameron, D.D.; Leake, J.R.; Read, D.J. Mutualistic mycorrhiza in orchids: evidence from plant-fungus carbon and nitrogen transfers in the green-leaved terrestrial orchid Goodyera repens. New Phytol. 2006, 171, 405-416. [CrossRef]

45. Cameron, D.D.; Johnson, I.; Read, D.J.; Leake, J.R. Giving and receiving: measuring the carbon cost of mycorrhizas in the green orchid, Goodyera repens. New Phytol. 2008, 180, 176-184. [CrossRef]

46. Ogura-Tsujita, Y.; Gebauer, G.; Hashimoto, T.; Umata, H.; Yukawa, T. Evidence for novel and specialized mycorrhizal parasitism: the orchid Gastrodia confusa gains carbon from saprotrophic Mycena. Proc. R. Soc. B. 2008, 276, 761-767. [CrossRef]

47. Afzal, I.; Shinwari, Z.K.; Sikandar, S.; Shahzad, S. Plant beneficial endophytic bacteria: Mechanisms, diversity, host range and genetic determinants. Microbiol. Res. 2019, 221, 36-49. [CrossRef]

48. Kuga, Y.; Sakamoto, N.; Yurimoto, H. Stable isotope cellular imaging reveals that both live and degenerating fungal pelotons transfer carbon and nitrogen to orchid protocorms. New Phytol. 2014, 202, 594-605. [CrossRef]

49. Tsavkelova, E.; Cherdyntseva, T.; Lobakova, E.; Kolomeitseva, G.; Netrusov, A. Microbiota of the orchid rhizoplane. Microbiology 2001, 70, 492-497. [CrossRef]

50. Tsavkelova, E.A.; Egorova, M.A.; Leontieva, M.R.; Malakho, S.G.; Kolomeitseva, G.L.; Netrusov, A.I. Dendrobium nobile Lindl. seed germination in co-cultures with diverse associated bacteria. Plant Growth Regul. 2016, 80, 79-91. [CrossRef]

51. Sandhya, V.; Ali, S.Z.; Grover, M.; Reddy, G.; Venkateswarlu, B. Effect of plant growth promoting Pseudomonas spp. on compatible solutes, antioxidant status and plant growth of maize under drought stress. Plant Growth Regul. 2010, 62, 21-30. [CrossRef]

52. Sharma, A.; Johri, B.; Sharma, A.; Glick, B. Plant growth-promoting bacterium Pseudomonas sp. strain GRP3 influences iron acquisition in mung bean (Vigna radiata L. Wilzeck). Soil Biol. Biochem. 2003, 35, 887-894. [CrossRef]

53. Otieno, N.; Lally, R.D.; Kiwanuka, S.; Lloyd, A.; Ryan, D.; Germaine, K.J.; Dowling, D.N. Plant growth promotion induced by phosphate solubilizing endophytic Pseudomonas isolates. Front. Microbiol. 2015, 6, 745. [CrossRef] 
54. Raheem, A.; Shaposhnikov, A.; Belimov, A.A.; Dodd, I.C.; Ali, B. Auxin production by rhizobacteria was associated with improved yield of wheat (Triticum aestivum L.) under drought stress. Arch. Agron. Soil Sci. 2018, 64, 574-587. [CrossRef]

55. Rath, M.; Mitchell, T.; Gold, S. Volatiles produced by Bacillus mojavensis RRC101 act as plant growth modulators and are strongly culture-dependent. Microbiol. Res. 2018, 208, 76-84. [CrossRef]

56. Bharti, N.; Yadav, D.; Barnawal, D.; Maji, D.; Kalra, A. Exiguobacterium oxidotolerans, a halotolerant plant growth promoting rhizobacteria, improves yield and content of secondary metabolites in Bacopa monnieri (L.) Pennell under primary and secondary salt stress. World J. Microbiol. Biotechnol. 2013, 29, 379-387. [CrossRef]

57. Guglielmetti, S.; Basilico, R.; Taverniti, V.; Arioli, S.; Piagnani, C.; Bernacchi, A. Luteibacter rhizovicinus MIMR1 promotes root development in barley (Hordeum vulgare L.) under laboratory conditions. World J. Microbiol. Biotechnol. 2013, 29, 2025-2032. [CrossRef]

58. Galdiano, J.R.F.; Pedrinho, E.A.N.; Castellane, T.C.L.; Lemos, E.G.d.M. Auxin-producing bacteria isolated from the roots of Cattleya walkeriana, an endangered Brazilian orchid, and their role in acclimatization. Rev. Bras. Ciênc. Solo 2011, 35, 729-737.

59. Herrera, H.; Novotná, A.; Ortiz, J.; Soto, J.; Arriagada, C. Isolation and identification of plant growth-promoting bacteria from rhizomes of Arachnitis uniflora, a fully mycoheterotrophic plant in southern Chile. Appl. Soil. Ecol. 2020, 149, 103512. [CrossRef]

60. Rout, M.E.; Southworth, D. The root microbiome influences scales from molecules to ecosystems: the unseen majority1. Am. J. Bot. 2013, 100, 1689-1691. [CrossRef]

61. Tsavkelova, E.; Cherdyntseva, T.; Netrusov, A. Auxin production by bacteria associated with orchid roots. Microbiology 2005, 74, 46-53. [CrossRef]

62. Tsavkelova, E.A.; Cherdyntseva, T.A.; Klimova, S.Y.; Shestakov, A.I.; Botina, S.G.; Netrusov, A.I. Orchid-associated bacteria produce indole-3-acetic acid, promote seed germination, and increase their microbial yield in response to exogenous auxin. Arch. Microbiol. 2007, 188, 655-664. [CrossRef]

63. Höppener-Ogawa, S.; de Boer, W.; Leveau, J.; Van Veen, J.; De Brandt, E.; Vanlaere, E.; Sutton, H.; Dare, D.J.; Vandamme, P. Collimonas arenae sp. nov. and Collimonas pratensis sp. nov., isolated from (semi-) natural grassland soils. Int. J. Syst. Evol. Microbiol. 2008, 58, 414-419. [CrossRef]

64. Garbeva, P.; Hordijk, C.; Gerards, S.; De Boer, W. Volatiles produced by the mycophagous soil bacterium Collimonas. FEMS Microbiol. Ecol. 2014, 87, 639-649. [CrossRef]

65. Poosakkannu, A.; Nissinen, R.; Kytöviita, M.M. Culturable endophytic microbial communities in the circumpolar grass, Deschampsia flexuosa in a sub-Arctic inland primary succession are habitat and growth stage specific. Environ. Microbiol. Rep. 2015, 7, 111-122. [CrossRef]

66. de Boer, W.; Leveau, J.H.; Kowalchuk, G.A.; Gunnewiek, P.J.K.; Abeln, E.C.; Figge, M.J.; Sjollema, K.; Janse, J.D.; van Veen, J.A. Collimonas fungivorans gen. nov., sp. nov., a chitinolytic soil bacterium with the ability to grow on living fungal hyphae. Int. J. Syst. Evol. Microbiol. 2004, 54, 857-864. [CrossRef]

67. Hoffman, M.T.; Gunatilaka, M.K.; Wijeratne, K.; Gunatilaka, L.; Arnold, A.E. Endohyphal bacterium enhances production of indole-3-acetic acid by a foliar fungal endophyte. PLoS ONE 2013, 8, e73132. [CrossRef]

(C) 2020 by the authors. Licensee MDPI, Basel, Switzerland. This article is an open access article distributed under the terms and conditions of the Creative Commons Attribution (CC BY) license (http://creativecommons.org/licenses/by/4.0/). 